\title{
Assessing the usefulness of the photogrammetric method in the process of capturing data on parcel boundaries
}

\author{
Piotr Benduch*, Agnieszka Pęska-Siwik \\ AGH University of Science and Technology \\ Faculty of Mining Surveying and Environmental Engineering \\ Department of Geomatics \\ 30 Mickiewicza Av., 30-059 Cracow, Poland \\ e-mails: pbenduch@agh.edu.pl; peska@agh.edu.pl \\ * Corresponding author: Piotr Benduch
}

Received: 31 January 2017 / Accepted: 6 April 2017

\begin{abstract}
A parcel is the most important object of real estate cadastre. Its primary spatial attribute are boundaries, determining the extent of property rights. Capturing the data on boundaries should be performed in the way ensuring sufficiently high accuracy and reliability. In recent years, as part of the project "ZSIN - Construction of Integrated Real Estate Information System - Stage I", in the territories of the participating districts, actions were taken aimed at the modernization of the register of land and buildings. In many cases, this process was carried out basing on photogrammetric materials. Applicable regulations allow such a possibility. This paper, basing on the documentation from the National Geodetic and Cartographic Documentation Center and on the authors' own surveys attempts to assess the applicability of the photogrammetric method to capture data on the boundaries of cadastral parcels. The scope of the research, most importantly, included the problem of accuracy with which it was possible to determine the position of a boundary point using photogrammetric surveys carried out on the terrain model created from processed aerial photographs. The article demonstrates the manner of recording this information in the cadastral database, as well as the resulting legal consequences. Moreover, the level of reliability of the entered values of the selected attributes of boundary points was assessed.
\end{abstract}

Keywords: accuracy, photogrammetry, record parcel, boundary, register of land and buildings

\section{Introduction}

Capturing data on the boundaries of record parcels is a complex process which should be carried out in a way ensuring sufficiently high accuracy and reliability of the final results. This means that if the data on the position of boundary points is not 
reliable, or if there is no such data, then it is necessary to determine the course of the boundaries and to measure the specific points in accordance with the applicable technical standards.

The problem of data capture for the cadastre using photogrammetric methods has already been the subject of Polish publications (Kurczyński, 2002). In most cases, the use of the photogrammetric methods in the process of recording spatial information on the boundaries of cadastral parcels was evaluated to be useful, mainly due to the shorter work time required for the procedure of determining the course of parcel boundaries (Kurczyński and Bakuła, 2016). Some authors also pointed out that the performance of a photogrammetric survey ensures the accuracy required for current technical standards (Kuklicz and Kuźnicki, 2015). In addition to reduction of measurements time, the lower costs of gathering spatial data are also pointed out as a benefit of the photogrammetric method. It can be relevant in the context of creating and running spatial data infrastructures (SDIs) (Zwirowicz-Rutkowska, 2016).

The issue of using photogrammetric methods to collect data for the real estate cadastre appears to have been known for many years in other countries as well (Weissmann, 1971; Williamson, 1983; Demir et al., 2008; Ali et al., 2012). World literature features an increase in the popularity of photogrammetric documentation in the context of building and improving the 3D cadastre (Aringer and Roschlaub, 2014; Jazayeri et al., 2014). Nevertheless, using photogrammetric surveys in the works involving capturing data on boundaries is still a current topic (Cunningham et al., 2011). Some research studies were conducted, which aimed to verify the applicability and accuracy of the photogrammetric documentation for recording spatial information on the course of boundaries (Siriba, 2009). The results of the photogrammetric surveys were compared with those of direct surveys (Alkan and Solak, 2010). The most recent trend in capturing data on the boundaries of cadastral parcels is using aerial photographs taken from unmanned aerial vehicle (UAV photogrammetry). The studies on the applicability and accuracy of this type of documentation have already been carried out (Manyoky et al., 2011; Sung and Lee, 2016).

In recent years, there has been a systematic increase in the popularity and scale of the use of photogrammetric methods in the process of capturing data on parcel boundaries. In the territories of numerous districts participating in the project "ZSIN - Construction of Integrated Real Estate Information System - Stage I", hereinafter referred to as ZSIN, the register of land and buildings was modernized, largely basing on photogrammetric materials. One of the purposes of carrying out this process is a widely understood improvement in the quality of the data entered into the real estate cadastre, including making them consistent with the requirements set out in the legislation. In order to verify whether this demand could be considered to have been met, an attempt was made to assess the applicability of the photogrammetric method in the process of capturing data on parcel boundaries within the selected cadastral district. 
The conducted analyses focused primarily on the issue of the accuracy, with which it was possible to determine the position of boundary points using photogrammetric surveys carried out on the terrain model. For the purpose of this research, the materials from the National Geodetic and Cartographic Documentation Center database were used. Also, the surveys of the control points were performed, with the use of the GNSS satellite technique, in order to compare the obtained results with the data contained in the modernized cadastre. So far, no publication has been noted which would deal with the practical verification of the accuracy of photogrammetric surveys of boundary points of record parcels, performed as part of the ZSIN project, through their direct control in the field carried out using satellite technology. The statistical methods proposed in this article have not been used so far for this type of analyses. This proves the originality of the approach proposed by the authors.

The scientific objective of this paper, first of all, is to examine the current quality of spatial information defining the extent of ownership rights to land, which was recorded using the increasing in popularity photogrammetric techniques. The authors focus on the verification of the level of reliability of the values of selected attributes of boundary points entered into the modernized cadastre. This is an important issue, with multi-faceted significance. In theory, attributes of boundary points are to represent, in a unified manner, the actual status of parcel boundaries in Poland. In practice, however, this requirement cannot always be regarded as met. For this reason, the measures taken enabled both assessing the applicability of modern photogrammetric techniques in the process of capturing data on boundaries, as well as allowed verification of the data contained in the basic public records describing the factual status of real property. The conducted studies are empirical, technical, and analytical. They can be regarded as a preliminary verification of the selected direction in the development and advancement of the cadastre in Poland.

\section{Record parcel and its boundaries}

According to the Regulation of the Minister of Regional Development and Construction of 29 March 2001 on the register of land and buildings (Regulation, 2001), the record parcel is a continuous area of land located within the boundaries of one cadastral district, uniform in legal terms, parceled out from the surrounding area by means of boundary lines. The definition demonstrates that the shape and surface area of the parcel are derivatives of its boundaries. On the other hand, Geodetic and Cartographic Law (Law, 1989) unambiguously demonstrates that the data contained in the register are the basis for economic planning, spatial planning, assessment of taxes and benefits, denotation of real property in mortgage and land registers, public statistics, real estate management and register of farms. This fact shows how important it is to reliably determine the course of boundaries and recording this information in a manner consistent with the applicable technical requirements (Hanus, 2006). If the spatial 
range of property rights is determined in an inappropriate way, the consequences of this status will be multi-faceted.

Taking the above considerations into account, the overall quality level of the information on the course of boundaries entered into the cadastral database depends on two aspects:

Quality of the data on the

boundaries of record parcels

Reliable determination of the course of the boundaries (in the presence of the parties)

Survey of the boundary points meeting the technical requirements

Fig. 1. Factors determining the quality of the data on the boundaries of record parcels

According to Figure 1, meeting the demand of improving the quality of the data on the boundaries of record parcels is possible only in the case of performing both of the specified actions. It is worth noting that, in accordance with Regulation (2001) unjustified failure to take part in the procedure of determining the course of boundaries will not be an obstacle for its performance. There is no doubt that this process cannot be considered equally reliable as when all the parties to the proceedings are present.

The procedure involving the determination of the course of parcel boundaries, in accordance with applicable laws (Regulation, 2001), may be carried out directly in the field or basing on aerial imaging, satellite imaging, or the orthophotomap characterized by a resolution providing visualization of the topographic details which may be important in determining the course of these boundaries. This option was used quite frequently during the implementation of the ZSIN project. The problem of the use of photogrammetric materials for the purpose of determining parcel boundaries is questionable and should be closely examined.

This article focuses primarily on testing the accuracy with which it is possible to determine the position of boundary points through photogrammetric surveys. Therefore, the second of the identified factors is analyzed, which together constitute a measure of the quality of the data on the boundaries of record parcels entered into the real estate cadastre. The existing regulations clearly specify the accuracy necessary for the surveys of the boundary points so that they could be included into the numerical description of boundaries. 
The numerical description of the boundaries of record parcels

The set of boundary points whose position in relation to the first-order geodetic control has been determined basing on the topographic surveys with mean errors not exceeding $0.30 \mathrm{~m}$

Fig. 2. Accuracy requirements for the numerical description of the boundaries

Flat rectangular coordinates of the boundary points which meet the above requirements are used, for example, to calculate surface areas of the parcels. If this condition is not met, then the surface areas entered into the register of land and buildings remain unchanged until the body running the cadastre obtains the data of the required accuracy (Regulation, 2013). Therefore, it is very important that the information on the accuracy with which the position of the boundary points was determined was provided in a reliable manner. This is also important in the context of the mean errors of the analytical determination of the surface areas of the parcels (Bieda et al., 2014).

It is worth noting that in accordance with Regulation (2011) the location of boundary points and boundary markers which belong to the first-order field details should be determined with a mean error of less than $0.10 \mathrm{~m}$ relative to the closest points of the horizontal geodetic control and the measurement control. Therefore, there is a discrepancy between the accuracy requirements of the numerical description of the boundaries and the principles contained in technical standards. Due to the gravity of the problem, this issue should be unified.

Anyway, previously mentioned accuracy cannot be obtained through the cartometric method, which over the years has become less useful and popular. In Doskocz (2013) it was indicated that the estimated average accuracy of situational point, achieved by cartometric measurement on the digitized analogue map, is likely to fluctuate in the range of $0.14-0.46 \mathrm{~m}$. The final value of the average error of the boundary point position, in this case, consists of, among others, error related to placing an item on the map, error of mathematical transformation maps and, finally, error related to digitised boundaries. Despite systematic works related to the modernization of the cadastre in Poland, in some areas the only available source of information about the boundaries of plots is still digitized analogue maps. In such case, a good solution seems to be to implement procedures for verifying the risk of any decision taken on the basis of data describing the spatial position of objects, acquired on the grounds of existing archival cartographic materials (Doskocz, 2016). 


\section{Boundary point}

Capturing the data on parcel boundaries is a term synonymous with the capture of the data on the location of boundary points. It also follows from the definition of a boundary contained in Regulation (2001), which states that it is a part of the perimeter of a cadastral parcel, in the form of a broken line or a section shared by two adjacent cadastral parcels or coinciding with the state border. In addition, the determination of the position of a boundary point and entering its flat rectangular coordinates into the database of the register of land and buildings is the only possible way to register the information about the spatial location of the boundary.

In order to meet the demands of harmonization and interoperability of the data contained in the real estate cadastre, UML (Unified Modeling Language) application schemes were introduced, which are contained in Appendix 1a to Regulation (2001). Pursuant to their contents, each boundary point, in addition to the identifier and flat rectangular coordinates expressed in the current system 2000, has also assigned appropriate attributes. Considering the problem of the quality of the data on the boundaries of record parcels, it is worth paying special attention to:

- data source on the boundary point position (the Polish acronym: ZRD),

- mean error of the boundary point position relative to the first-order geodetic control (the Polish acronym: BPP),

The values which can be assigned to those attributes with the corresponding definitions are presented in Table 1 and Table 2. It should be considered controversial that, despite the subsequent amendments to Regulation (2001), the information which is so essential, for both the surveying contractors and the authorities running the register of land and buildings, is still contained in the Appendix, and not in the main body of the applicable implementing act.

These attributes put together may provide a measure of the quality of the data on the boundaries of record parcels (Felcenloben, 2015). Therefore, it is very important to reliably and duly assign appropriate values to them. This issue is one of the subjects of these studies and analyses. In Table 2, those values of the BPP attribute, whose assignment was equivalent to meeting the technical requirements of the numerical description of the boundaries, were additionally marked in bold.

Over the years, permissible values and definitions of the attributes of a boundary point have changed. As it was mentioned, inter alia, by (Benduch and Pęska, 2016), their comprehensive update was not carried out. For this reason, the information that would enable to verify the wording of the legal provisions in force at the date of the introduction of the specific value of the boundary point attribute to the database should also be entered into the register of land and buildings. 
Table 1. Data source on the boundary point position (ZRD)

\begin{tabular}{|c|c|}
\hline Value & Definition \\
\hline 1 & $\begin{array}{l}\text { Field surveys preceded by real estate delimitation, restoration of boundary markers, } \\
\text { determination of boundary points or of their position in a different mode, including } \\
\text { the one specified in } \S 39 \text { sections } 1 \text { and } 2 \text { of the Regulation (2001). }\end{array}$ \\
\hline 2 & $\begin{array}{l}\text { Field surveys not preceded by real estate delimitation, restoration of boundary markers, } \\
\text { determination of boundary points or of their position in a different mode. }\end{array}$ \\
\hline 3 & $\begin{array}{l}\text { Photogrammetric surveys of boundary points, the location of which has previously } \\
\text { been determined as set out in } \S 37 \text { section } 2 \text { of the Regulation (2001), as well as } \\
\text { photogrammetric measurements of boundary markers visualized on aerial photographs } \\
\text { or on a orthophotomap, as a result of their signaling before taking photographs. }\end{array}$ \\
\hline 4 & $\begin{array}{l}\text { Photogrammetric surveys not preceded by the determination of the course of the } \\
\text { boundaries of cadastral parcels or signaling boundary markers before taking aerial } \\
\text { photographs. }\end{array}$ \\
\hline 5 & Approved projects of real estate subdivision or reparcelling and subdivision. \\
\hline 6 & Approved projects of reparcelling or exchange of land. \\
\hline 7 & $\begin{array}{l}\text { Screen vectorization of the cadastral raster map using the results of field surveys } \\
\text { (linear tie distances). }\end{array}$ \\
\hline 8 & $\begin{array}{l}\text { Screen vectorization of the cadastral raster map without using the results of field } \\
\text { surveys. }\end{array}$ \\
\hline 9 & $\begin{array}{l}\text { Data sources, other than ZRD1 - ZRD8, including the results of findings and analyses } \\
\text { referred to in } \S 39 \text { section } 3 \text { of the Regulation (2001). }\end{array}$ \\
\hline
\end{tabular}

Source: Own study based on Regulation (2001)

Table 2. Mean error of the boundary point position relative to the first-order geodetic control (BPP)

\begin{tabular}{|c|c|}
\hline Value & Definition \\
\hline $\mathbf{1}$ & $\mathbf{0 . 0 0} \mathbf{~ m}-\mathbf{0 . 1 0} \mathbf{~}$ \\
\hline $\mathbf{2}$ & $\mathbf{0 . 1 1} \mathbf{~ m}-\mathbf{0 . 3 0} \mathbf{~}$ \\
\hline 3 & $0.31 \mathrm{~m}-0.60 \mathrm{~m}$ \\
\hline 4 & $0.61 \mathrm{~m}-1.50 \mathrm{~m}$ \\
\hline 5 & $1.51 \mathrm{~m}-3.00 \mathrm{~m}$ \\
\hline 6 & above $3.00 \mathrm{~m}$ \\
\hline
\end{tabular}

Source: Own study based on Regulation (2001) 


\section{Capturing the data on the parcel boundaries basing on photogrammetric materials}

According to the Regulation (2001), the data on the location of boundary points can be captured through field surveys, photogrammetric surveys, as well as, in specific cases, using cartometric surveys. Depending on the undertaken actions aimed at collecting data on the boundaries of record parcels, each boundary point is assigned appropriate values of the ZRD attribute. Basing on the information in Table 1, it can be concluded that the legislature distinguishes between two groups of boundary points subject to photogrammetric survey:
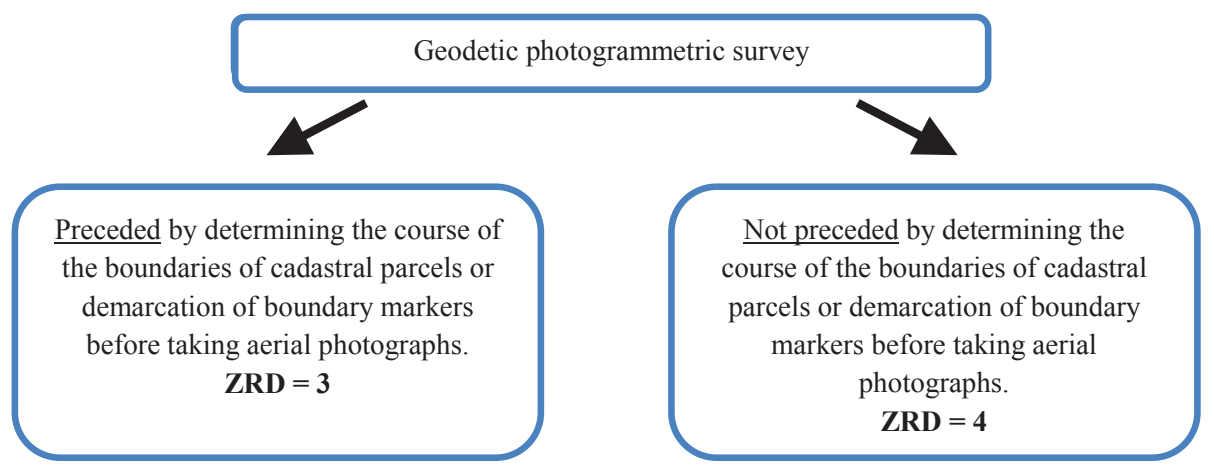

Fig. 3. Geodetic photogrammetric survey in the light of the legislation on the cadastre

Referring to $\S 37$ section 2 of Regulation (2001), the determination of the course of parcel boundaries, including the position of the boundary points defining them, can be performed basing on the aerial imaging, satellite imaging, or the orthophotomap having an appropriate resolution, which is the size of the ground pixel providing visualization of topographic details which may be significant in determining the course of these boundaries. The legislator, unfortunately, does not specify which topographic details may be important when implementing this procedure. The issue of the accuracy of their identification also requires some consideration.

The analyzed legal provision allows a determination of the course of parcel boundaries without going out to the field. These steps must, however, be distinguished from geodetic photogrammetric survey which, in accordance with the Regulation on technical standards is defined as the geodetic topographic or detailed survey, performed on a terrain model created from processed aerial photographs, for which elements of the orientation were determined in the process of aerial triangulation. A geodetic photogrammetric survey is performed exclusively in the technology of digital photogrammetric analysis.

The process of capturing data on parcel boundaries with the photogrammetric method is associated with a number of limitations. They result, e.g. from the lack of visibility of the boundary points obscured by tree canopies, buildings, or other 
elements of infrastructure. The season in which the surveying missions are carried out is also of great importance (Wróbel, 2015). In mountain areas it happens that boundaries run along the slopes which are not sufficiently visible in processed aerial photographs. In $\S 44$ of Regulation (2011) it is stated that photogrammetric surveys must be revised and complemented by comparing the content of the aerial photos with the terrain, and by performing necessary topographic field surveys. These activities, in relation to the boundary corner points, are to verify the correctness of the performed identification and to complement the missing data.

\section{The problem of accuracy of the data captured using the photogrammetric method}

A significant drawback related to the data on the boundaries of cadastral parcels captured using the photogrammetric surveys are minimal possibilities to assess their accuracy. The photogrammetric method allows obtaining the coordinates of a corner point of the parcel boundary identified on the terrain model or orthophotomap. These coordinates are usually the only evidence of the photogrammetric surveys performed by the observer. Other documentation concerns the widely understood quality of aerial photos and their processing. So far, the literature has not provided an algorithm which would allow an unambiguous identification of the accuracy with which the position of field details is determined using photogrammetric surveys. The issue of referring the values of these errors to the first-order geodetic control is also problematic.

According to the explanations of the Central Office of Geodesy and Cartography regarding the implementation of $\S 37$ section 2 Regulation (2001) in the context of public procurement carried out under the ZSIN project, the accuracy of determining the position of a topographic point by the method of photogrammetric surveying, should fall within the following range:

- $\mathrm{m}_{\mathrm{XY}} \leq 0.40 \mathrm{~m} \div 0.50 \mathrm{~m}$ - for the photographs at a scale of $1: 13000$,

- $\mathrm{m}_{\mathrm{XY}} \leq 0.75 \mathrm{~m} \div 0.90 \mathrm{~m}$ - for the photographs at a scale of 1:26 000 .

Taking also into account factors such as the ability to precisely identify topographic details relevant to the determination of the course of boundaries and the perception of the person performing photogrammetric survey, boundary point position errors not exceeding $0.10 \mathrm{~m}$ relative to the first-order geodetic control $(\mathrm{BPP}=1)$ do not seem fully reliable. The terrain model itself is not a flawless study, either (Paszotta and Szumiło, 2006), similarly as the orthophotomap which is characterized by geometric errors as a consequence of the errors of the exterior orientation, digital terrain model errors and the errors resulting from simplifications of the application performing the processing (Technical Guidelines, 2000).

At this point, it is also worth referring to the technical conditions containing a description of the works carried out in the analyzed area, related to the modernization of the register of land and buildings, which were issued by the appropriate 
district authorities. Pursuant to their contents, the performance of photogrammetric surveys was acceptable to acquire information needed to calculate the coordinates of boundary points belonging to the boundaries of the parcels not covered by the compact development, and to developed plots of land on which buildings were situated at a distance greater than $1.5 \mathrm{~m}$ from the boundaries, if their course had been previously agreed with the parties involved. The photogrammetric survey could be performed on the terrain model created with processed aerial or satellite photographs of the ground pixel size not exceeding $0.25 \mathrm{~m}$. The cartometric survey of boundary points on the orthophotomap created from the aerial photographs of the ground pixel size not exceeding $0.10 \mathrm{~m}$ was also considered to be acceptable. It should be noted that it is quite common to equate the size of the ground pixel to the accuracy with which the position of a topographic detail was determined, but that opinion is too generalized.

\section{Research methodology}

Due to the increasing popularity of the photogrammetric method of capturing data on parcel boundaries, proven by its wide use during the ZSIN project, an attempt was made to verify the accuracy of the results obtained by using this method. It was decided that using the procedure based on a practical comparison of the data contained in the register of land and buildings with the results of own topographic surveys would be the most effective. At the stage of the office work preceding the performance of actual surveys, a total of 300 evenly distributed boundary points were determined, unambiguously identifiable on the ortophotomap which was used in the modernization process. In addition to the boundary points of the ZRD attribute value equal to 3, the survey also covered the points of the ZRD attribute values of 1,5 , and 9 . This approach aimed to compare the quality of the data on parcel boundaries, captured using the direct and the photogrammetric methods. Additionally, thanks to the obtained results, it was possible to assess the reliability of the values of the attributes of the boundary points entered into the cadastral database.

Basing on the results of the performed field work, the coordinates of the boundary points entered into the register of land and buildings were compared with the coordinates obtained during the GNSS RTN satellite measurements based on the system of ASG-EUPOS reference stations. It is commonly assumed that determining the horizontal position of a field detail using the RTN method in standard measurement conditions including the correction data of the NAWGEO service is carried out with a mean error of no more than $0.03-0.05 \mathrm{~m}$, relative to the first-order horizontal geodetic control (Łuczyński, 2011).

In this way, at specific control points, linear deviations were estimated, understood as: 


$$
\mathrm{dL}_{\mathrm{i}}=\sqrt{\left(\mathrm{X}_{\mathrm{pi}}-\mathrm{X}_{\mathrm{ei}}\right)^{2}+\left(\mathrm{Y}_{\mathrm{pi}}-\mathrm{Y}_{\mathrm{ei}}\right)^{2}}
$$

where: $\mathrm{dL}_{\mathrm{i}}$ - linear deviation at the $\mathrm{i}$-th control point; $\mathrm{X}_{\mathrm{p}}, \mathrm{Y}_{\mathrm{pi}}-$ coordinates of the $\mathrm{i}$-th boundary point, captured during the performed surveys; $\mathrm{X}_{\mathrm{e}}, \mathrm{Y}_{\mathrm{ei}}$ - coordinates of the i-th boundary point, entered into the modernized real estate cadastre.

Therefore, the coordinates of the boundary points obtained during the control survey were treated as real values. This procedure reveals that the results of field work were adopted as a reference point. They were considered error-free. On the other hand, the data entered into the cadastre were verified. Further, the results were statistically adjusted. The outliers were removed and the point and interval estimations were performed for the specified parameters, including the structure index of the boundary points recorded in the modernized database, which comply with applicable technical standards. The final inference was performed taking into account the relevant adjustment due to the possibility of identifying the positions of boundary points in the field.

\section{Description of the research area}

In order to perform the analyses aimed at assessing the applicability of the photogrammetric method in the process of collecting data on parcel boundaries, the selected research area was one of the cadastral districts participating in the implementation of the ZSIN project. This choice was not accidental. In the area in question, located in the mountain regions of Poland (southern part of the Małopolska province), in the fourth quarter of the year 2015 the modernization of the register of land and buildings based on the photogrammetric materials prepared by the contractor was completed. As of the first quarter of 2016, the selected cadastral district covered 34,051 record parcels. The surface area of the entire district slightly exceeded 10,000 hectares. $71 \%$ of this area was covered by forests and wooded land, $24 \%$ by agricultural land, and the remaining 5\% were built-up areas and urban areas. The scope of the research was limited primarily to built-up and urban areas, which contributed to the increased possibility of a correct identification of control points in the field.

Table 3 contains the full information on the number of the boundary points of the record parcels with specific values of the ZRD and BPP attributes.

The section referring to the data on the parcel boundaries which were captured using photogrammetric method, was additionally marked in bold. All the boundary points which were assigned the ZRD attribute value equal to 3 obtained the BPP attribute at a level of 1 . This means that the mean error of the analyzed 4,590 boundary points, according to the information entered after the modernization of the cadastre, does not exceed $0.10 \mathrm{~m}$ relative to the first-order geodetic control. On the other hand, the accuracy with which the positions of boundary points were 
determined using photogrammetric surveys not preceded by determining the course of boundaries $(\mathrm{ZRD}=4)$, was at the level of $1.51-3.00 \mathrm{~m}$ relative to the first-order geodetic control. It is worth noting that these were the points located on the boundary of the cadastral district. One of the boundary points was assigned the value of the BPP attribute equal to 2 .

Table 3. ZRD and BPP attributes of the boundary points of the record parcels in the analyzed cadastral district

\begin{tabular}{|c|c|c|c|c|c|c|c|c|c|c|c|}
\hline BPP & lack & 1 & 2 & 3 & 4 & 5 & 6 & 7 & 8 & 9 & In total \\
\hline lack & 3 & 0 & 0 & $\mathbf{0}$ & $\mathbf{0}$ & 0 & 0 & 0 & 0 & $\mathbf{0}$ & 3 \\
\hline 1 & 0 & 84 & 0 & $\mathbf{4 5 9 0}$ & $\mathbf{0}$ & 6 & 0 & 0 & 1 & $\mathbf{0}$ & 4681 \\
\hline 2 & 0 & 11386 & 0 & $\mathbf{0}$ & $\mathbf{1}$ & 5573 & 1 & 0 & 0 & $\mathbf{8 8 5 4 1}$ & 105502 \\
\hline 3 & 0 & 0 & 0 & $\mathbf{0}$ & $\mathbf{0}$ & 0 & 0 & 0 & 0 & $\mathbf{0}$ & 0 \\
\hline 4 & 0 & 0 & 0 & $\mathbf{0}$ & $\mathbf{0}$ & 0 & 0 & 0 & 177 & $\mathbf{0}$ & 177 \\
\hline 5 & 0 & 0 & 0 & $\mathbf{0}$ & $\mathbf{5 3 7}$ & 0 & 0 & 0 & 140 & $\mathbf{0}$ & 677 \\
\hline 6 & 0 & 0 & 0 & $\mathbf{0}$ & $\mathbf{0}$ & 0 & 0 & 0 & 0 & $\mathbf{0}$ & 0 \\
\hline In total & 3 & 11470 & 0 & $\mathbf{4 5 9 0}$ & $\mathbf{5 3 8}$ & 5579 & 1 & 0 & 318 & $\mathbf{8 8 5 4 1}$ & 111040 \\
\hline
\end{tabular}

Source: Own study based on the materials from the district geodetic and cartographic documentation center database

In Table 3, the set of 88,541 boundary points with the assigned ZRD attribute value of 9 and the BPP attribute value equal to 2 were highlighted as well; they were entered into the register of land and buildings after the modernization. On the inclusion of the record of survey and property description to the cadastral database, which took place in the fourth quarter of 2015, the definition of the ZRD attribute value equal to 9 sounded as follows: screen vectorization of cartographic studies other than the cadastral map.

It cannot be excluded either that the contractor of surveying works, in agreement with the geodetic and cartographic documentation center, assigned attribute values of boundary points which were consistent with the definition contained in the draft Regulation, which was subject to amendment at that time (Regulation, 2015). When the modernized data supplied the register of land and buildings, the above definition of the ZRD attribute of 9 was still in force. Anyway, it proves the use of a nonstandard procedure for collecting information about parcel boundaries which, as it turns out, is based on photogrammetric materials. $98.2 \%$ of boundary points of the ZRD attribute value equal to 9 have the additional designation "ORTHO". Referring to the previously discussed technical conditions, it seems likely that the cartometric survey will be carried out on the orthophotomap. Unfortunately, at the district geodetic and cartographic documentation center it was impossible to obtain unambiguous 
information about why such a large collection of the corner points of parcel boundaries was assigned the specific values of the attributes, or how, in practice, the process of data acquisition was going. It is important that in accordance with applicable legal regulations, these points meet the technical requirements of the numerical description of the boundaries, and thus their coordinates were used to calculate the surface areas of the parcels.

\section{Results of the practical verification of the accuracy of the data on the parcel boundaries captured by the photogrammetric method}

According to the adopted research methodology, in order to carry out appropriate analyses, it was necessary to capture the data on the positions of the selected boundary points directly in the field. Finally, the GNSS satellite survey based on the system of ASG-EUPOS reference stations determined the location of 287 corner points of parcel boundaries. In the case of 36 control points, the direct identification in the field carried out on the basis of the orthophotomap turned out to be incorrect, and therefore the results of those surveys were not used in the further analysis.

Table 4 demonstrates the number of boundary points of the specified values of the ZRD and BPP attributes, which were covered by the control survey.

Table 4. The number of boundary points of the specified values of the ZRD and BPP attributes, which were subject to the control survey

\begin{tabular}{|c|c|c|}
\hline ZRD attribute & BPP attribute & The number of boundary points \\
\hline 1 & 2 & $\mathbf{5 3}$ \\
\hline 5 & 2 & $\mathbf{1 0}$ \\
\hline 3 & 1 & $\mathbf{1 4 9}$ \\
\hline 9 & 2 & $\mathbf{3 9}$ \\
\hline
\end{tabular}

Source: Own study

The above table illustrates that according to the information contained in the register of land and buildings, all the analyzed boundary points meet technical requirements of the numerical description of the boundaries (Figure 2). Nevertheless, the mean linear deviation estimated for all 251 control points was at the level of $0.74 \mathrm{~m}$. Assuming the error-free survey performed using the GNSS satellite technique, and assuming that the calculated deviation $\mathrm{dL}_{\mathrm{i}}$ corresponds to the actual value of the errors of the boundary point positions entered into the cadastre, the following conclusions were formulated:

- 112 of the analyzed boundary points meet technical requirements of the numerical description of the boundaries,

- 139 of the boundary points do not meet these requirements, 
- the percentage of the boundary points that meet the technical requirements of the numerical description of the boundaries is $44.6 \%$.

The presented considerations also took into account the possibility of a proper identification of the boundary corner points in the field. It was determined at the level of $0.10 \mathrm{~m}$, which corresponds to the accuracy of the location of field details belonging to the first-class accuracy (Regulation, 2011). This means that the calculated linear deviation $\mathrm{dL}_{\mathrm{i}}$ reached the value of less than $0.40 \mathrm{~m}$ only in the case of 112 out of 251 control points. Once again, it should be emphasized that the survey covered only these boundary points which were clearly identifiable in the field, primarily the corner points and the corners of the fences.

In order to further increase the reliability of the research results, the outliers were removed $\left(\mathrm{dL}_{\mathrm{i}}>\mathrm{dL}_{\mathrm{sr}}+\sigma\right)$ from among the boundary points of the same value of the ZRD attribute. In this way, another 35 measured control points were excluded from the analysis. The results of applying this procedure are demonstrated in Table 5.

Table 5. Mean linear deviation $\mathrm{dL}_{\mathrm{sr}}$ of the boundary points, depending on the ZRD attribute - after the removal of the outliers

\begin{tabular}{|c|c|c|c|c|c|}
\hline ZRD & $\begin{array}{c}\text { Sample } \\
\text { size }\end{array}$ & $\begin{array}{c}\mathrm{dL}_{\text {sr }} \text { estimator } \\
{[\mathrm{m}]}\end{array}$ & $\begin{array}{c}\text { Accuracy of the } \\
\mathrm{dL}_{\text {sr }} \text { estimator } \\
{[\mathrm{m}]}\end{array}$ & $\begin{array}{c}\text { Result of the interval estimation } \\
\text { of the value of } \mathrm{dL}_{\text {sr }} \text { for } \mathrm{P}=95 \% \\
{\left[\mathrm{~m}^{2}\right.}\end{array}$ \\
\hline 1 & 46 & $\mathbf{0 . 3 9}$ & \pm 0.06 & $\mathbf{0 . 2 8}$ & $\mathbf{0 . 4 9}$ \\
\hline 5 & 7 & $\mathbf{0 . 2 5}$ & \pm 0.07 & $\mathbf{0 . 0 7}$ & $\mathbf{0 . 4 3}$ \\
\hline 3 & 131 & $\mathbf{0 . 5 0}$ & \pm 0.03 & $\mathbf{0 . 4 4}$ & $\mathbf{0 . 5 6}$ \\
\hline 9 & 32 & $\mathbf{0 . 8 9}$ & \pm 0.11 & $\mathbf{0 . 6 7}$ & $\mathbf{1 . 1 0}$ \\
\hline
\end{tabular}

Source: Own study

Basing on the above comparison, it is possible to conclude that the mean linear deviation $\mathrm{dL}_{\mathrm{sr}}$ estimated for the data on the parcel boundaries captured by the direct method ( $Z R D=1$ and 5$)$ is lower than in the case of the data captured using the photogrammetric method ( $Z R D=3$ and 9 ). The result of the interval estimation of the value of $\mathrm{dL}_{\text {sr }}$ for the boundary points of the $\mathrm{ZRD}$ attribute value equal to 3 , at $95 \%$ confidence level, does not fall within the interval corresponding to technical requirements of the numerical description of the boundaries. In this regard, taking adjustments into account does not help either, due to the identification of the topographic details subjected to the control survey. This conclusion is confirmed by the performed parametric statistical test (Figure 4). 
$\mathbf{H}_{0}$ : The photogrammetric survey in the analyzed area, performed as part of the modernization, which allowed to meet the technical requirements of the numerical description of the boundaries $\left(\mathrm{dL}_{\mathrm{sr}} \leq 0.40 \mathrm{~m}\right)$
$\mathbf{H}_{1}$ : The photogrammetric survey in the analyzed area, performed as part of the modernization, which did not allow to meet the technical requirements of the numerical description of the boundaries $\left(\mathrm{dL}_{\mathrm{sr}}>0.40 \mathrm{~m}\right)$

Mean linear deviation $\mathrm{dL}_{\mathrm{sr}}: 0.50 \mathrm{~m}$

Value of the test function $\mathrm{Z}$ for the normal distribution: 3.4651

Boundary of one-tailed critical region $\mathrm{Z}_{(0,95)}: 1.6448$

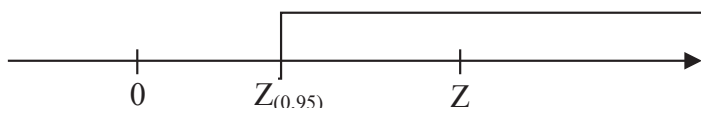

Conclusion: The value of the test function falls within the critical region, which forms the basis for rejecting the null hypothesis $\left(\mathbf{H}_{\mathbf{0}}\right)$ and acceptance of the alternative hypothesis $\left(\mathbf{H}_{\mathbf{1}}\right)$. The photogrammetric survey of the boundary points in the study area did not allow to meet the technical requirements of the numerical description of the boundaries.

Fig. 4. Testing the hypothesis of meeting the accuracy requirements of the numerical description of the boundaries of cadastral parcels by the considered set of boundary points

The presented inference applies only to the boundary points of the ZRD attribute value equal to 3 . In the case of the boundary points with the value of the ZRD attribute at the level of 9 , the situation is even more obvious. This means that the use of the photogrammetric method of capturing data on parcel boundaries in the selected mountain area, characterized by a relatively high density of development, has not produced the expected results. The conducted analyses lead to conclusion that the use of geodetic field surveys for register of land and buildings purposes still seems to be a preferable solution, especially in the aspect of gathering data regarding the course of parcel boundaries. It is also worth noting, that study on accuracy level improvements of field survey results is constantly in progress. One of the latest proposals is implementation of innovative empirical methods for reducing the observations in geodetic networks (Kadaj, 2016).

The obtained result does not definitely rule out the usefulness of the photogrammetric method in the process of capturing data on the parcel boundaries in other areas. The conducted studies, however, cast some doubts on the opinions which were previously published in Polish literature (Kuklicz and Kuźnicki, 2015; Kurczyński and Bakuła, 2016) on the high level of applicability of the photogrammetric method when performing the tasks associated with capturing data for the needs of the real estate cadastre. The publication (Alkan and Solak, 2010) demonstrated similar discrepancies between the coordinates of the turn points of parcel boundaries captured during the GNSS RTN satellite surveys, and the coordinates determined using photogrammetric surveys. Due to the specific conditions in which the cadastre in Poland has evolved 
over the years, as well as the existence of different legal regulations in other countries, comparing the results of such analyses with foreign studies is not fully reliable.

The graph below (Figure 5) illustrates the values of the linear deviations $\mathrm{dL}_{\mathrm{i}}$ (after removing the outliers) for the 131 boundary points covered by the survey, which were used for the implementation of the research studies.

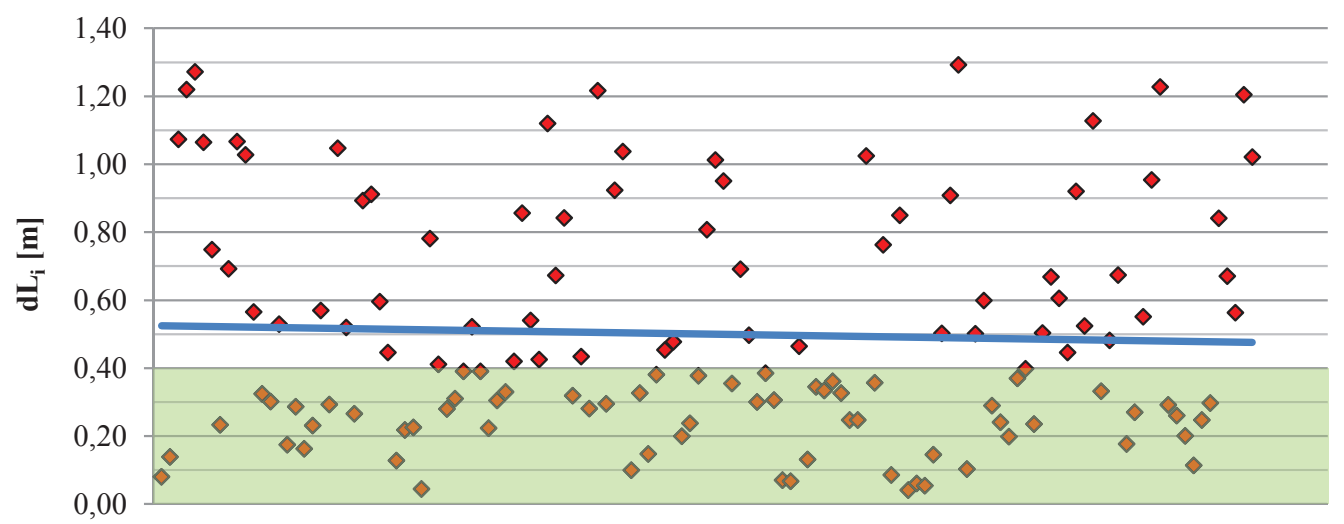

Fig. 5. Scatter of the linear deviations $\mathrm{dL}_{\mathrm{i}}$ of the boundary points $(\mathrm{ZRD}=3, \mathrm{BPP}=1)$

The area with the boundary points which meet the technical requirements of the numerical description of the boundaries was marked in green. With the earlier assumption that $\mathrm{dL}_{\mathrm{i}} \leq 0.40 \mathrm{~m}$ is a proof that the desired accuracy of determining the position of the boundary point is maintained, this condition was met by 67 out of 131 points, which accounts for $51.1 \%$. For comparison, in the case of the boundary corner points with the ZRD attribute value of 9 this percentage was only $34.4 \%$. It should be noted that the course of the plotted blue trend line was nearly horizontal. This demonstrates the uniformity of the conditions under which the GNSS RTN satellite measurement of the successive control points in the study area was carried out, which additionally strengthens the reliability of the obtained results. There were no correlations identified between the values of the linear deviations $\mathrm{dL}_{\mathrm{i}}$ and the locations of specific objects in the area which was the subject of the analyses.

The study also covered the reliability of the information entered into the cadastre, regarding the accuracy with which the position of boundary points was determined with the use of the photogrammetric materials developed during the modernization. This issue raised concerns from the very beginning. The conducted studies demonstrate that, in accordance with the adopted assumptions, the percentage of boundary points which are assigned the appropriate value of the BPP attribute is as follows: 
Table 6. Index of the structure of the boundary points which meet the accuracy requirements appropriate for the assigned value of the BPP attribute

\begin{tabular}{|c|c|c|c|c|c|c|}
\hline ZRD & BPP & $\begin{array}{c}\text { Sample } \\
\text { size }\end{array}$ & $\begin{array}{c}\text { Estimator of the } \\
\text { structure (fraction) } \\
\text { index }\end{array}$ & $\begin{array}{c}\text { Accuracy of } \\
\text { the fraction } \\
\text { estimator }\end{array}$ & \multicolumn{2}{|c|}{$\begin{array}{c}\text { Result of the interval } \\
\text { estimation of the structure } \\
\text { index for } \mathrm{P}=95 \%\end{array}$} \\
\hline 3 & 1 & 131 & $\mathbf{1 6 . 0} \%\left(\mathrm{dL}_{\mathrm{i}} \leq 0.20 \mathrm{~m}\right)$ & $\pm 3.2 \%$ & $\mathbf{1 3 . 1 \%}$ & $\mathbf{1 9 . 5 \%}$ \\
\hline 9 & 2 & 32 & $\mathbf{3 4 . 4 \%}\left(\mathrm{dL}_{\mathrm{i}} \leq 0.40 \mathrm{~m}\right)$ & $\pm 8.4 \%$ & $\mathbf{1 8 . 6 \%}$ & $\mathbf{5 3 . 2 \%}$ \\
\hline
\end{tabular}

Source: Own study

The conclusions formulated from Table 6 confirm that the reliability of the information entered into the real estate cadastre, regarding the accuracy, with which the position of the boundary points was determined, is low. The values of the BPP attribute are usually assigned depending on the ZRD attribute or depending on performed actions, basing on which the data on the parcel boundary was captured. A full assessment of the accuracy is not carried out. This brings about very negative, multi-faceted consequences. It should be emphasized once again that all of the controlled boundary points, according to the information entered into the cadastral database, meet the applicable technical requirements with reference to acceptable error values. The analyses carried out so far have demonstrated that this is not fully consistent with the real situation. Due to the gravity of this problem, it should be subjected to further research.

\section{Conclusions}

The conducted studies and analyses allowed the following conclusions:

- The measure of the quality of the data on parcel boundaries entered into the register of land and buildings should be, for example, values of the ZRD and BPP attributes of the boundary points, analyzed together. It is very important to reliably assign appropriate values to them. Unfortunately, the values of the BPP attribute, especially those entered into the cadastral database, may be questionable. They are usually declared by surveying contractors exclusively on the basis of the procedure used to capture information on the location of boundary points. A complete assessment of accuracy is not performed, which is confirmed by research results. The consequences of providing unreliable information determining the accuracy which the position of a boundary point was defined with are multi-faceted. Assigning the BPP attribute value equal to 2 to a boundary point is equivalent to the inclusion of this point into the numerical description of the boundaries. Then, the coordinates of the boundary points are used to calculate the surface area of the parcel, which is used directly to carry out statutory tasks of the real estate cadastre. Due to the average level of reliability of the recorded values of boundary point attributes, the resulting surface areas will 
be subject to uncertainty, as well as the spatial extent of ownership rights to land. Taking into account the means appropriated in recent years for the modernization of the cadastre and the implementation of the ZSIN project, the reservations regarding the development of the cadastre in Poland should be considered reasonable.

- The use of the photogrammetric method of capturing data on the parcel boundaries within the studied cadastral district participating in the implementation of the ZSIN project, in the majority of cases, did not in fact allow meeting the accuracy requirements of the numerical description of the boundaries. This is confirmed by the results of geodetic field surveys at control points, as well as statistical tests taking into account the possibility to identify specific boundary points directly in the field. One of the causes of the described situation might be errors made by the person carrying out photogrammetric surveys, resulting from insufficient level of their training to carry out the work related to the comprehensive modernization of the real estate cadastre. The reason could also lie in the description of the area. Proper identification of boundaries in mountain urban areas, basing on photogrammetric materials, is often unfeasible. All in all, the photogrammetric method in the studied area did not contribute to the fulfillment of the demands of the equally high accuracy, and consequently the reliability of the data contained in the modernized register of land and buildings.

- The conclusions drawn from the performed analyses do not unambiguously demonstrate the low applicability of the photogrammetric method for capturing data on the boundaries of parcels. This method, however, should not be treated as a fully universal tool. The conducted analysis is an important argument in the ongoing in Poland discussion about the applicability of the photogrammetric techniques, which are still being refined, to perform the tasks associated with data collection for the needs of the real estate cadastre. The study results, similar to those obtained by (Alkan and Solak, 2010), form the basis to draw the conclusion that photogrammetric materials may be an important reference document in the work related to the modernization of the register of land and buildings. According to the authors, treating them as a basic tool for capturing spatial information regarding the course of parcel boundaries is not justified. In future, this problem will be subject to further and broader research.

\section{Acknowledgments}

This article is the result of examinations financed from means for statutory activities no. 11.11.150.006 in the Department of Geomatics, AGH University of Science and Technology, Cracow, Poland. 


\section{References}

Ali, Z., Tuladhar, A. and Zevenbergen, J. (2012). An integrated approach for updating cadastral maps in Pakistan using satellite remote sensing data. International Journal of Applied Earth Observation and Geoinformation, 18, 386-398. DOI: 10.1016/j.jag.2012.03.008

Alkan, M. and Solak, Y. (2010). An investigation of 1: 5000 scale photogrammetric data for cadastral mapping uses: A case study of Kastamonu-Taskopru. African Journal of Agricultural Research, 5(18), 2576-2588.

Aringer, K. and Roschlaub, R. (2014). Bavarian 3D building model and update concept based on LiDAR, image matching and cadastre information. Innovations in 3D Geo-Information Sciences. Springer International Publishing, pp. 143-157.

Benduch, P. and Pęska, A. (2016). Comparison of the methods of capturing data concerning parcel boundaries in aspects of their accuracy and reliability. In International Geographic Information Systems Conference and Exhibition "GIS ODYSSEY 2016", 5 $5^{\text {th }}$ to $9^{\text {th }}$ September 2016 (pp. 25-34). Perugia, Italy: Croatian Information Technology Society - GIS Forum.

Bieda, A., Hanus, P., Jasińska, E. and Preweda, E. (2014). Accuracy of determination of real estate area. In the 9th International Conference "Environmental engineering", 22-23 May 2014 (pp. 1-7). Vilnius, Lithuania: Vilnius Gediminas Technical University Press Technika. DOI: 10.3846/enviro.2014.191

Cunningham, K., Walker, G., Stahlke, E. and Wilson, R. (2011). Cadastral audit and assessments using unmanned aerial systems. In the International Conference on Unmanned Aerial Vehicle in Geomatics (UAV-g), 14-16 September 2011 (pp. 213-216). Zurich, Switzerland: International Society for Photogrammetry and Remote Sensing.

Demir, O., Uzun, B. and Çete, M. (2008). Turkish cadastral system. Survey Review, 40(307), 54-66. DOI: $10.1179 / 003962608 X 253484$

Doskocz, A. (2013). Methodology for assessing the accuracy of digital large-scale maps. Dissertations and Monographs, 193, University of Warmia and Mazury in Olsztyn, Poland.

Doskocz, A. (2016). Accuracy assessment of planimetric large-scale map data for decision-making. Geodesy and Cartography, 65(1), 3-12. DOI: 10.1515/geocart-2016-0006

Felcenloben, D. (2015). Ocena jakości danych ewidencyjnych oraz efektywności funkcjonowania katastru nieruchomości. ISBN: 978-83-7717-219-3. Wrocław, Poland: Wydawnictwo UWP.

Hanus, P. (2006). Ocena przydatności dokumentacji bylego katastru austriackiego dla potrzeb prac geodezyjnych. Unpublished PhD thesis, AGH University of Science and Technology, Cracow, Poland.

Jazayeri, I., Rajabifard, A. and Kalantari, M. (2014). A geometric and semantic evaluation of 3D data sourcing methods for land and property information. Land Use Policy, 36, 219-230. DOI: 10.1016/j. landusepol.2013.08.004

Kadaj, R. (2016). Empirical methods of reducing the observations in geodetic networks. Geodesy and Cartography, 65(1), 13-40. DOI: 10.1515/geocart-2016-0001

Kuklicz, P. and Kuźnicki, W. (2015). Zdjęcia lotnicze - skuteczna metoda na EGiB. Magazyn geoinformacyjny Geodeta, 6, 18-20.

Kurczyński, Z. and Bakuła, K. (2016). Ocena możliwości współczesnej fotogrametrii w pracach z zakresu ewidencji gruntów i budynków. Przegląd Geodezyjny, 88(7), 2-10. DOI: 10.15199/50.2016.7.1

Kurczyński, Z. (2002). Modernizacja ewidencji gruntów i budynków na terenach gdzie funkcjonują mapy ewidencyjne w skali 1: $2880 \mathrm{z}$ wykorzystaniem metod fotogrametrii cyfrowej. Archiwum Fotogrametrii, Kartografii i Teledetekcji, 12, 203-215.

Łuczyński, R. (2011). Historyczne $i$ współczesne technologie pomiarowe $w$ aspekcie potrzeb katastru nieruchomości. Science session on occasion of 90th anniversary of Faculty of Geodesy and Cartography existing, 27-28 May 2011. Warszawa, Poland: Politechnika Warszawska.

Manyoky, M., Theiler, P., Steudler, D. and Eisenbeiss, H. (2011). Unmanned aerial vehicle in cadastral applications. ISPRS-International Archives of the Photogrammetry, Remote Sensing and Spatial Information Sciences, 3822, 57-62. DOI: 10.5194/isprsarchives-XXXVIII-1-C22-57-2011 
Paszotta, Z. and Szumiło, M. (2006). Źródła błędów numerycznego modelu terenu pozyskanego metodami fotogrametrycznymi. Геодезія, картографія і аерофотознімання: украйнський міжвідомчий науково-технічний збірник / Міністерство освіти і науки Украйни, Національний університет „Львівська політехніка” ; відповідальний редактор П. М. Зазуляк. - Львів : Видавнищтво Національного університету «Львівська політехніка», Випуск 67, 44-51.

Siriba, D. (2009). Positional Accuracy Assessment of a Cadastral Dataset based on the Knowledge of the Process Steps used. In the 12th AGILE Conference on GIScience, June 2-5 2009. Hannover, Germany: Association of Geographic Information Laboratories in Europe.

Sung, S. M. and Lee, J. O. (2016). Accuracy of Parcel Boundary Demarcation in Agricultural Area Using UAV-Photogrammetry. Journal of the Korean Society of Surveying, Geodesy, Photogrammetry and Cartography, 34(1), 53-62. DOI: 10.7848/ksgpc.2016.34.1.53

Regulation of the Minister of Administration and Digitalization of 29 November 2013 amending the regulation on the register of land and buildings (Official Journal 2013, No. 0, item 1551).

Regulation of the Minister of Administration and Digitalization of 6 November 2015 amending the regulation on the register of land and buildings (Official Journal 2015, No. 0, item 2109).

Regulation of the Minister of Internal Affairs and Administration of 9 November 2011 on the technical standards for the performance of horizontal and height measurements and processing as well as transferring results of these measurements to the National Geodetic and Cartographic Resource (Official Journal 2011, No. 263, item 1572).

Regulation of the Minister of Regional Development and Construction of 29 March 2001 on the register of land and buildings (Official Journal 2016, No. 0, item 1034 - consolidated text, as amended).

The Act of 17 May 1989 Geodetic and Cartographic Law (Official Journal 2015, No. 0, item 520 - consolidated text, as amended).

Technical Guidelines. The rules of preparing orthophotomaps in scale 1:10000. Central Office of Geodesy and Cartography, Warszawa, 2000.

Weissmann, K. (1971). Photogrammetry applied to cadastral survey in Switzerland. The Photogrammetric Record, 7(37), 5-15.

Williamson, I. P. (1983). Cadastral survey techniques in developing countries - with particular reference to Thailand. Australian surveyor, 31(7), 496-512.

Wróbel, A. (2015). Possibilities to verify spatial data of real estate using archival aerial photogrammetric images. In International Geographic Information Systems Conference and Exhibition "GIS ODYSSEY 2015", $7^{\text {th }}$ to $11^{\text {th }}$ September 2015 - Modern Geodetic Techniques in Spatial Measurement (pp. 26-40). Perugia, Italy: Croatian Information Technology Society - GIS Forum.

Zwirowicz-Rutkowska, A. (2016). On the use of IT investment assessment methods in the area of spatial data infrastructure. Geodesy and Cartography, 65(1), 111-122. DOI: 10.1515/geocart-2016-0005 